\title{
СТРОКИ ЗБИРАННЯ ТА ПІСЛЯЗБИРАЛЬНЕ ДОЗРІВАННЯ НАСІННЯ РІПАКУ ЯРОГО
}

Н. В. Солодюк, А. М. Кирильчук

ННЦ «Інститут землеробства НААН»

Встановлено строки збирання селекційних зразків ріпаку ярого без зниження посівних і товарних якостей насіння.

Ріпак ярий, селекиійний зразок, фаза дозрівання,схожість насіння

Вступ. Відповідальним моментом у технології вирощування ріпаку ярого є збирання врожаю.

Визначити час збирання ріпаку доволі складно, бо рослини достигають неодночасно. Крім того, ріпак достигає дуже швидко: зранку поле було ще сизо-зелене, а надвечір може набрати характерного для стиглості жовтозеленого кольору $[1,10,12]$.

Початок цвітіння зазвичай настає за накопичення середньодобових температур повітря 735-800 ${ }^{\circ} \mathrm{C}[6,8]$. Сума активних температур, необхідна для формування врожаю насіння становить $1800-2100{ }^{\circ} \mathrm{C}$ [13]. Встановлено, що надто раннє збирання недостиглого насіння знижує схожість, а перестій призводить до значних втрат - 25-30 і більше відсотків [11].

Під час збирання великих об`ємів селекційного матеріалу строки збирання подовжуються (розтягуються), що призводить до розтріскування стручків і втрат цінних зразків. Тому доцільно приступати до збирання, не чекаючи повної стиглості, але у фазі, що забезпечує високу польову схожість насіння. У зв`язку з цим виявлення фази дозрівання (зелений стручок, молочна, воскова, повна стиглість) початку збирання селекційних зразків ріпаку ярого $є$ актуальним.

Отже, зважаючи на такі особливості культури, перед достиганням потрібно пильно стежити за полем, бо запізнення, навіть на декілька днів, призводить до значних втрат урожаю. Цих втрат можна уникнути тільки тоді, коли початок збирання ріпаку буде завчасним.

Мета і завдання дослідження полягає у виявленні оптимальних строків збирання та тривалості періоду післязбирального дозрівання селекційних зразків ріпаку ярого без зниження посівних і товарних якостей насіння.

Методика досліджень. Дослідження проводили в 2007-2012 роках у восьмій зернопросапній сівозміні Державного підприємства Дослідне

(C) Н. В. Солодюк, А. М. Кирильчук. 2013.

ISSN 0582-5075. Селекція і насінництво. 2013. Випуск 103. 
господарство «Чабани» ННЦ «Інститут землеробства НААН» на чорноземно-лучному карбонатно середньо-суглинковому грунті з умістом в орному шарі (0-20 см) гумусу 3,7 \%; реакція грунтового розчину слабокисла pH 5,7 сольової витяжки; азоту, що легко гідролізується - 14,3 мг/100 г грунту (за Корнфільдом); рухомого фосфору та обмінного калію (за Чириковим) - 22,0 та 21,8 мг/100 г грунту, з використанням загальноприйнятих методик $[2,3,9,10]$.

Результати і їх обговорення. Завданням дослідження було виявити, в якій фазі дозрівання (не чекаючи повної стиглості) можна починати збирати селекційні зразки, щоб запобігти осипанню і втрати насіння i, разом 3 тим, виявити найкращий час збирання ріпаку ярого для отримання олії, яка за своїми якостями близька до оливової.

3 цією метою, після того, як цвітіння закінчилося і стручки сформувались, через кожні п`ять днів збирали пагони зі стручками (фази «зелений стручок», «наливу зерна», «воскова стиглість», «повна стиглість»). У день збирання відбирали наважку масою 100 г і ставили на висушування, не відділяючи стручки від пагонів, для того, щоб насіння не втрачало зв язку 3 місцем прикріплення до стручка і достигало в нормальних умовах.

Вміст вологи у зразках зеленої маси $(\mathrm{V})$ обчислювали у відсотках від маси зразка за формулою (1).

$$
V=\frac{\mathrm{m} 1-\mathrm{m} 2}{\mathrm{~m} 1-\mathrm{m} 0} \times 100
$$

де $\mathrm{m}_{\mathrm{o}}$ - маса посудини, $г$; $\mathrm{m}_{1}$ - маса посудини 3 пробою до висушування, г; $\mathrm{m}_{2}$ - маса посудини 3 пробою після висушування, г [5].

Після висушування маси визначали кількість стручків на масу наважки і вологість насіння, масу 1000 насінин, відсоток достиглого насіння на 100 насінин (табл. 1).

Вміст вологи та летких речовин у фазу «зеленого стручка» становив 78,5-82,5 \%, у фазі «повної стиглості» він зменшився до 28,8-29,3 \%. Як показали дослідження, збільшення маси 1000 насінин починалося у фазі «воскової стиглості» і становило 1,3-1,5 г, а у насіння, зібраного у фазі «зеленого стручка» - 1,2-1,3 г, при цьому відсоток стручків на 100 г наважки зріс на 32,8 \%. За роки досліджень виявлено мінливість показника кількості стручків на 100 г наважки від $\pm 9,4$ до $\pm 31,1$ шт. та маси 1000 насінин від $\pm 0,1$ до $\pm 0,5$ г.

Для визначення енергії проростання за ДСТУ 4138-2002 [4] у чашках Петрі на змоченому дистильованою водою фільтрувальному папері розташовували 100 насінин ріпаку ярого і ставили у темне місце за температури $20{ }^{\circ} \mathrm{C}$. Облік пророслого насіння проводили на п`ятий день і визначали енергію проростання. На сьомий день проводили остаточний облік схожості насіння. 
Таблиця 1

Фази дозрівання і якість зерна зразків ріпаку ярого, 2007-2010 pр.

\begin{tabular}{|c|c|c|c|c|c|c|c|c|c|}
\hline \multirow{2}{*}{ 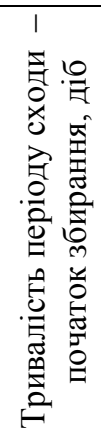 } & \multirow[b]{2}{*}{$\begin{array}{c}\text { Фаза } \\
\text { дозріван- } \\
\text { ня насін- } \\
\text { ня }\end{array}$} & \multirow[b]{2}{*}{ 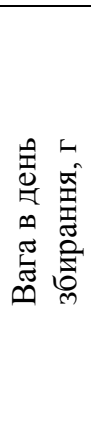 } & \multirow[b]{2}{*}{ 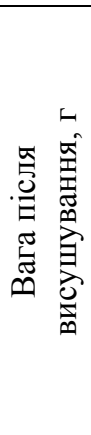 } & \multirow[b]{2}{*}{ 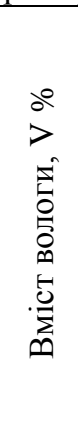 } & \multicolumn{3}{|c|}{$\begin{array}{c}\text { Розподіл за } \\
\text { кольором, \% }\end{array}$} & \multirow[b]{2}{*}{ 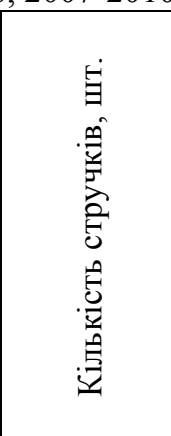 } & \multirow{2}{*}{ 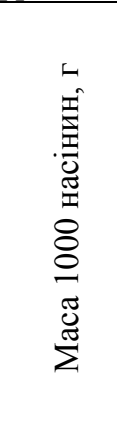 } \\
\hline & & & & & 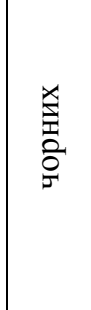 & 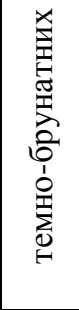 & 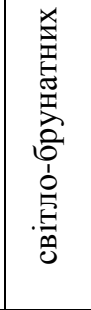 & & \\
\hline 78 & \multirow{2}{*}{$\begin{array}{l}\text { зелений } \\
\text { стручок }\end{array}$} & 100 & 17,5 & 82,5 & 0,0 & 6,3 & 93,8 & $145,3 \pm 9,4$ & $1,3 \pm 0,2$ \\
\hline 83 & & 100 & 21,5 & 78,5 & 0,0 & 54,8 & 45,3 & $156,8 \pm 21,9$ & $1,2 \pm 0,1$ \\
\hline 88 & \multirow{2}{*}{$\begin{array}{l}\text { налив } \\
\text { зерна }\end{array}$} & 100 & 20,2 & 79,8 & 0,0 & 82,3 & 17,8 & $161,8 \pm 11,4$ & $1,3 \pm 0,2$ \\
\hline 93 & & 100 & 20,6 & 79,5 & 0,0 & 87,0 & 13,0 & $162,0 \pm 12,8$ & $1,5 \pm 0,1$ \\
\hline 98 & \multirow{3}{*}{$\begin{array}{l}\text { воскова } \\
\text { стиглість }\end{array}$} & 100 & 32,9 & 67,1 & 17,3 & 34,0 & 47,8 & $193,0 \pm 10,2$ & $3,5 \pm 0,3$ \\
\hline 104 & & 100 & 36,0 & 64,0 & 18,5 & 41,5 & 40,0 & $193,0 \pm 7,9$ & $3,8 \pm 0,5$ \\
\hline 109 & & 100 & 37,4 & 62,7 & 66,0 & 27,0 & 7,0 & $205,0 \pm 11,3$ & $3,4 \pm 0,3$ \\
\hline 114 & \multirow{2}{*}{$\begin{array}{l}\text { повна } \\
\text { стиглість }\end{array}$} & 100 & 71,2 & 28,8 & 94,5 & 5,5 & 0,0 & $422,3 \pm 26,3$ & $4,0 \pm 0,2$ \\
\hline 119 & & 100 & 70,7 & 29,3 & 95,5 & 4,5 & 0,0 & $426,3 \pm 31,1$ & $4,2 \pm 0,5$ \\
\hline & \multicolumn{2}{|l|}{$\mathrm{Sx}$} & \multicolumn{2}{|l|}{3,9} & 7,8 & 6,0 & 5,8 & 21,2 & 0,3 \\
\hline & \multicolumn{2}{|l|}{$\begin{array}{l}\mathrm{V}, \% \\
\mathrm{HIP}_{05}\end{array}$} & \multicolumn{2}{|l|}{$\begin{array}{l}57,3 \\
11,5\end{array}$} & $\begin{array}{c}127,1 \\
22,6\end{array}$ & $\begin{array}{l}82,9 \\
17,3\end{array}$ & $\begin{array}{c}104,0 \\
16,8\end{array}$ & $\begin{array}{l}48,9 \\
61,5\end{array}$ & $\begin{array}{c}49,0 \\
0,7\end{array}$ \\
\hline
\end{tabular}

Дослідженнями виявлено, що у сформованого на 50 \% та зібраного у фазі «зеленого стручка» насіння, енергія проростання (у середньому) за роки досліджень становила 17,0 \%, схожість насіння коливалась від 18,2 до $27,0 \%$, мінливість за роки виявлена у межах від $\pm 3,3$ до $\pm 4,0$ та від $\pm 1,7$ до $\pm 9,5 \%$ відповідно (табл. 2).

У фазі «воскової стиглості» схожість насіння коливалась від 57,2 до 60,8 \%, у фазі «повної стиглості» - 95,4-97,3 \%. Виявлено чіткі відмінності між фазами розвитку посівних якостей насіння ріпаку ярого. Проте стабілізація енергії проростання та схожості насіння відбувається лише через 23-26 діб після збирання. Таким чином, після проходження післяжнивного достигання встановлюються однаково високі посівні якості насіння ріпаку ярого незалежно від строків збирання. Зважаючи на висновки ряду науковців про втрати врожаю при осипанні у фазі «повної стиглості» на $70 \%$ та у фазі «воскової стиглості» - 20 \% всього врожаю, ми можемо не тільки знизити втрати, а й уникнути їх. 
Посівні якості та хімічний склад насіння колекційних зразків ріпаку ярого залежно від фаз дозрівання, \%, 2007-2010 рр.

\begin{tabular}{|c|c|c|c|c|c|c|c|}
\hline $\begin{array}{c}\text { Фаза дозрі- } \\
\text { вання }\end{array}$ & 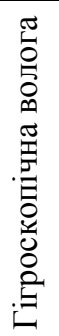 & 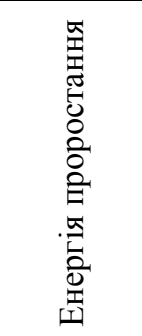 & 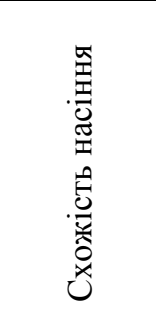 & $\begin{array}{l}\text { Вміст } \\
\text { жиру }\end{array}$ & $\begin{array}{c}\text { Вміст } \\
\text { протеїну }\end{array}$ & $0_{n}^{\infty}$ & 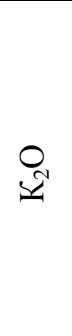 \\
\hline \multirow{2}{*}{$\begin{array}{l}\text { зелений } \\
\text { стручок }\end{array}$} & 6,7 & $17,0 \pm 4,0$ & $18,2 \pm 1,7$ & $45,6 \pm 0,5$ & $20,8 \pm 0,4$ & 1,4 & 1,1 \\
\hline & 6,9 & $16,9 \pm 3,3$ & $27,0 \pm 9,5$ & $45,9 \pm 0,8$ & $20,3 \pm 1,1$ & 1,5 & 0,8 \\
\hline \multirow[t]{2}{*}{ налив зерна } & 7,3 & $11,8 \pm 7,9$ & $30,0 \pm 21,1$ & $45,2 \pm 0,4$ & $22,1 \pm 1,5$ & 1,5 & 0,8 \\
\hline & 7,7 & $13,4 \pm 9,4$ & $34,2 \pm 23,5$ & $45,1 \pm 0,5$ & $20,7 \pm 2,5$ & 1,5 & 0,8 \\
\hline \multirow{3}{*}{$\begin{array}{l}\text { воскова } \\
\text { стиглість }\end{array}$} & 7,0 & $24,2 \pm 4,3$ & $59,9 \pm 8,7$ & $44,0 \pm 0,5$ & $21,7 \pm 0,6$ & 1,6 & 0,8 \\
\hline & 7,6 & $25,4 \pm 3,0$ & $60,8 \pm 4,6$ & $43,7 \pm 0,5$ & $22,0 \pm 0,2$ & 1,6 & 0,9 \\
\hline & 7,6 & $28,4 \pm 1,9$ & $57,2 \pm 14,1$ & $43,9 \pm 0,5$ & $22,0 \pm 0,6$ & 1,6 & 0,8 \\
\hline \multirow{2}{*}{$\begin{array}{l}\text { повна } \\
\text { лість }\end{array}$} & 7,6 & $91,9 \pm 1,9$ & $97,3 \pm 2,2$ & $41,9 \pm 1,8$ & $23,1 \pm 1,7$ & 1,6 & 0,7 \\
\hline & 7,2 & $90,9 \pm 3,2$ & $95,4 \pm 4,0$ & $41,1 \pm 1,6$ & $23,6 \pm 1,4$ & 1,6 & 0,8 \\
\hline Sx & 0,1 & 6,1 & 5,5 & 0,3 & 0,2 & 0,0 & 0,0 \\
\hline $\mathrm{V}, \%$ & 5,0 & 90,5 & 54,1 & 3,8 & 5,0 & 4,7 & 14,3 \\
\hline $\mathrm{HIP}_{05}$ & 0,2 & 17,6 & 15,8 & 0,9 & 0,6 & 0,0 & 0,1 \\
\hline
\end{tabular}

Паралельно зроблений біохімічний аналіз насіння, зібраного у різних фазах достигання, виявив, що вміст жиру в насінні фази «зелений стручок» (45,6-45,9 \%) порівняно до насіння фази «повна стиглість» $(41,1-41,9 \%)$ вище на 4,0-4,5 \% $\left(\mathrm{HIP}_{05}=0,9\right)$.

Зі зниженням вмісту жиру в насінні вміст протеїну підвищувався і у фазі «повної стиглості» становив 23,6 \%, що на 2,8 \% вище порівняно 3 насінням, зібраними у фазі «зеленого стручка» $\left(\mathrm{HIP}_{05}=0,6, \mathrm{r}=-0,92\right)$. Мінливість за роки досліджень у вищеназваних показників коливалась від $\pm 0,4$ до $\pm 1,8 \%$ та від $\pm 0,2$ до $\pm 2,5 \%$ відповідно.

Практично період збирання насіння визначається такими ознаками: лимонно-жовтий колір стручків; листя буріє, в яне й опадає; стебло підсихає, втрачає еластичність; більша частка стручків пожовкла, менша - почала жовтіти, проте пожовклі стручки ще м які та не розтріскуються; насіння в стручках вже тверде і досить розвинене, але тільки починає набувати властивого йому темного забарвлення, тому частина його червонуватого кольору, друга частина - темно-червонуватого (вишневого кольору), третя частина - жовтуватого та деяка частина насіння ще світла і тільки почала забарвлюватися у місці свого прикріплення. 
Дослідженнями виявлено, у насінні, зібраному у фазу «зеленого стручка», стабілізація енергії проростання та схожості насіння відбувається лише через 23-26 діб після збирання. Проте після проходження післяжнивного достигання встановлюються однаково високі посівні якості насіння ріпаку ярого незалежно від строків збирання і збільшення кількості стручків з 145,3 у фазу «зеленого стручка» до 426,3 шт. у фазу «повної стиглості». Відповідно відбувається збільшення маси 1000 насінин з 1,2-1,3 г до 4,04,2 г і схожості насіння з 18,2-27,0 \% до 95,4-97,3 \%. Найвищий вміст жиру в насінні $(45,6-45,9 \%)$ накопичувався у фазу «зеленого стручка», надалі 3 досягненням повної стиглості вміст жиру знизився на $1,25 \%$ і становив 41,1-41,9 \%. Між вмістом жиру в насінні та протеїну встановлено пряму обернену кореляцію $(\mathrm{r}=-0,92)$.

Отже, проведені дослідження показали, що збирання селекційних розсадників та насінних ділянок ріпаку ярого можна проводити без зниження посівних і товарних якостей насіння у фазу «зеленого стручка», завдяки чому ми зможемо не тільки знизити, а й уникнути втрат цінних форм.

Висновок. Стабілізація енергії проростання насіння, зібраного у фазі «воскова стиглість», відбувається через 23-26 діб після збирання, найбільший вміст жиру в насінні припадає на фази «зелений стручок» $(45,75 \%)$ та «наливу зерна» $(45,15 \%)$, отже збирання матеріалу ріпаку ярого в селекційних розсадниках та насінних ділянках можна проводити без зниження посівних і товарних якостей насіння у фазі «зеленого стручка» та «наливу зерна» роздільним способом.

\section{Список використаних джерел}

1. Горбатовский $О$. О. - Руководство к возделыванию озимого и ярового рапса / О. О. Горбатовский - С.-Петербург. Издание А. Ф. Дервиена. 1892. $-85 \mathrm{c}$.

2. Доспехов Б. А. Методика полевого опыта / Б. А. Доспехов. - М.: Колос, 1973. $-336 \mathrm{c}$.

3. Доспехов Б. А. Методика полевого опыта: [уч.пособ.] / Б. А. Доспехов. М.: Колос, $1985 .-423 \mathrm{c}$.

4. ДСТУ 4138-2002 Насіння сільськогосподарських культур. Методи визначення якості. - К.: Держспоживстандарт України, 2004. - 8 с.

5. ДСТУ ISO 771:2006 Макуха та шроти олійного насіння. Визначення вмісту вологи та летких речовин (ISO 771:1977, IDT). - К.: Держспоживстандарт України, 2008. - 8 с.

6. Интенсивная технология возделывания и использование рапса в Западной Сибири: Методические рекомендации / СибНИИСХ. - Новосибирск, 1988. $-92 \mathrm{c}$.

7. Кудрявцева A. А. Методика и техника постановки полевого опыта на стационарных участках / А. А. Кудрявцева. - Москва, 1949. - 272 с. 
8. Либа И. Г. Рапс возделывать выгодно / И. Г. Либа // Сельское хозяйство нечерноземья. Ежемесячный научно-производственный журнал Министерства сельского хозяйства РСФСР для нечерноземной зоны. - 1981. № 4. - C. 29-30.

9. Молостов А. С. Методика полевого опыта / А. С. Молостов. - Москва: «Колос», 1966. - $240 \mathrm{c}$.

10. Оробченко В. П. Ріпак (рапс) озимий та ярий / В. П. Оробченко. - Харків, Держсільгоспвидав. - 1932. - 184 с.

11. Ріпак. Ботанічна характеристика. Біологічні особливості. Селекція і насінництво. Технологія вирощування. Використання. // [В. Д. Гайдаш, М. М. Климчук, М. М. Макар, Г. В. Юхимчик та ін.] за ред. В. Д. Гайдаша - Івано-Франківськ „Сіверсія”, 1998. - 223 с.

12. Синская E. H. Межвидовое скрещивание культурных Brassica (генносистематические исследования) / Е. Н. Синская - Труды по прикладной ботанике, генетике и селекции. - Л.: ВИР, 1927. - Т. XVII. - Вып. 1. C. $3-166$

13. Яровой рапс на корм и семена в нечерноземной зоне: Интенсивная технология (Рекомендации). - Гос. агропром. ком. СССР. - М.: Агропромиздат, 1988. - 40 c. 